\title{
Hubungan Penggunaan Gawai dengan Keterlambatan Bahasa pada Anak
}

\author{
Rae Fernandez, Hesti Lestari \\ Departemen Ilmu Kesehatan Anak Fakultas Kedokteran Universitas Sam Ratulangi RSUP Prof. dr. R.D. Kandou Manado
}

Latar belakang. Gawai adalah perkembangan teknologi yang dapat menyebabkan ketergantungan penggunanya. Saat menggunakan gawai, anak-anak menjadi kurang interaktif dan komunikatif. Hal ini menyebabkan anak-anak mengalami keterlambatan perkembangan bahasa.

Tujuan. Menganalisis hubungan antara intensitas penggunaan gawai dan keterlambatan bahasa pada anak

Metode. Merupakan penelitian analitik potong lintang. Sampel adalah anak berusia 15 hingga 36 bulan di empat fasilitas penitipan anak usia dini di daerah Manado, periode Februari hingga April 2018. Kriteria inklusi adalah anak dengan berat lahir normal dan kelahiran cukup bulan. Kriteria eksklusi meliputi anak dengan cacat bawaan dan riwayat penyakit yang dapat memengaruhi perkembangan bahasa. Metode pengambilan sampel adalah purposive sampling. Intensitas penggunaan gawai yang disarankan adalah kurang dari 2 jam per hari, dan frekuensi kurang dari 2 hari per minggu. Keterlambatan bahasa didefinisikan menggunakan Skala CAPUTE, dengan DQ CLAMS $<85$. Metode analisis data yang digunakan adalah uji chi-square (nilai $\mathrm{p}<0,05$ ).

Hasil. Sampel terdiri dari 51 anak, $33(62 \%)$ di antaranya adalah perempuan. Usia rata-rata adalah 2 tahun 5 bulan (SD 0,6). Didapatkan $3(5,8 \%)$ anak mengalami keterlambatan bahasa, 10 (19,6\%) anak menggunakan gawai lebih dari 2 jam per hari dan 36 $(70,5 \%)$ anak menggunakan gawai lebih dari 2 hari per minggu. Ada hubungan yang signifikan antara intensitas penggunaan gawai lebih dari 2 jam dan keterlambatan bahasa $(\mathrm{p}=0,034)$, sementara tidak ada hubungan bermakna antara frekuensi penggunaan gawai lebih dari 2 hari per minggu dan keterlambatan bahasa $(\mathrm{p}=0,144)$.

Kesimpulan. Didapati hubungan yang signifikan antara intensitas penggunaan gawai lebih dari 2 jam per hari dengan keterlambatan bahasa. Sebaliknya, tidak ada hubungan bermakna antara frekuensi penggunaan gawai lebih dari 2 hari per minggu dan keterlambatan bahasa. Sari Pediatri 2019;21(4):231-5

Kata kunci: gawai, keterlambatan bahasa, anak

\section{The Relationship between Intensity of Gadget Usage and Speech Delayed in Children}

Rae Fernandez, Hesti Lestari

Background. The gadget is a technological development that can cause addiction to its users. When using a gadget, children become less interactive and communicative. This causes children to have delayed development in speech and language.

Objective. The aim of this study was to analyzed the relationship between the intensity of gadget usage and speech delayed in children. Methods. This was an analytic cross sectional study. Samples were children aged 15 to 36 months in four early child care facilities in Manado areas, from February to April 2018. The inclusion criteria were children with normal birth weight and term deliveries. Exclusion criteria include children with congenital defects and history of the disease that may affect speech development. The sampling method was purposive sampling. The intensity of gadget usage recommended is less than 2 hours per day, and a frequency of less than 2 days per week. Speech delayed was defined using CAPUTE Scale, with DQ CLAMS < 85. Data analysis method employed was chi-square test (p-value $<0.05$ ).

Results. From 51 children, 33 were girls (62\%). The mean age was 2 year 5 months (SD 0.6). There were 3 (5.8\%) children have speech delayed, $10(19.6 \%)$ children use gadget more than 2 hours per day and $36(70.5 \%)$ children use gadget more than 2 days per week. There was a significant relationship between the intensity of gadget usage more than 2 hours and speech delayed ( $\mathrm{p}=0.034)$, while there was no relationship between frequency of gadget usage more than 2 days per week and speech delayed ( $\mathrm{p}=0.144$ ).

Conclusion. There is a significant relationship between intensity of gadget usage more than 2 hours per day with speech delayed and there is no relationship between gadget usage more than 2 days per week and speech delayed. Sari Pediatri 2019;21(4):231-5

Keyword: gadget, speech delayed, children

Alamat korespondensi: Rae Fernandez. Departemen Ilmu Kesehatan Anak Fakultas Kedokteran Universitas Sam Ratulangi. Jl. Tanawangko. Email: raefernandez@gmail.co 


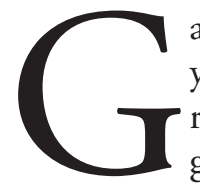

awai merupakan perkembangan teknologi yang dapat diterima di kalangan masyarakat dan seringkali menimbulkan ketergantungan. ${ }^{1}$ The American Academy of Pediatrics (AAP) menyatakan batas waktu anak menghabiskan waktu di depan gawai, yaitu satu atau dua jam per hari dan mencegah paparan media screen pada anak usia di bawah usia dua tahun. ${ }^{2}$ Waktu yang digunakan anak-anak untuk menggunakan gawai terlalu tinggi, rata-rata 2 jam sehari pada anak usia 2-4 tahun dan rata-rata 2 jam 20 menit pada anak usia 5-8 tahun. ${ }^{3}$

Dengan berkembangnya keterampilan ekspresif anak, kemampuan berbahasa menjadi lebih mudah diamati. Periode 2-4 tahun pertama menunjukkan peningkatan yang cepat dalam jumlah dan kompleksitas perkembangan berbahasa, kekayaan perbendaharaan kata, dan kontrol neuromotorik. ${ }^{4}$ Anak yang mengalami keterlambatan perkembangan dideskripsikan sebagai seorang anak yang memerlukan waktu lebih lama untuk mencapai milestones perkembangan dibandingkan dengan anak seusianya. ${ }^{5,6}$ Keterlambatan ini mencakup keterlambatan motorik halus, motorik kasar, bicara/ berbahasa, personal sosial/ interaksi sosial, kognitif dan aktivitas sehari-hari. ${ }^{7}$

Insiden keterlambatan perkembangan bahasa pada balita di Indonesia cukup tinggi. Jumlah balita (0-4 tahun) di Indonesia tahun 2014 sebesar 9,54\% dari seluruh populasi. ${ }^{8}$

Saat menggunakan gawai, anak menjadi kurang interaktif dan komunikatif. Hal ini menyebabkan anak mengalami keterlambatan perkembangan bicara dan bahasa. ${ }^{9}$ Penelitian menunjukkan bahwa sejak menggunakan gawai, ketika di rumah anak menjadi susah diajak berkomunikasi, tidak peduli, dan kurang berespon pada saat orang tua mengajaknya berbahasa. ${ }^{10,11}$ Anak dengan tingkat ketergantungan gawai, memiliki sedikit kesempatan untuk berinteraksi dengan orang lain. ${ }^{12}$

Anak-anak dengan paparan gawai yang tinggi mungkin memiliki kemampuan bahasa ekspresif yang rendah dan kemungkinan gangguan berbahasa. Meskipun keterampilan bahasa ekspresif menengah dikaitkan dengan penggunaan gawai, penyebab dan efek spesifik dari hubungan tersebut belum diidentifikasi. ${ }^{13,14}$

Berdasarkan pemaparan tersebut peneliti ingin mengetahui apakah terdapat hubungan antara intensitas penggunaan Gawai dan keterlambatan bahasa pada anak.

\section{Metode}

Penelitian ini menggunakan pendekatan studi analitik potong lintang. Pengambilan sampel dilakukan terhadap anak berusia 15 hingga 36 bulan di empat fasilitas penitipan anak usia dini di daerah Manado, sebanyak 51 anak yang dilakukan periode Februari hingga April 2018.

Kriteria inklusi adalah anak dengan berat lahir normal dan kelahiran cukup bulan. Kriteria eksklusi meliputi anak dengan cacat bawaan dan riwayat penyakit yang dapat memengaruhi perkembangan bicara dan bahasa. Sampel diambil dengan metode purposive sampling.

Instrumen pengumpulan data menggunakan angket yang dibuat sendiri untuk melihat penggunaan gawai pada anak. Angket ini ditujukan untuk orangtua masing-masing anak. Intensitas penggunaan gawai yang disarankan adalah kurang dari 2 jam per hari, dan frekuensi kurang dari 2 hari per minggu. Capute scales merupakan alat skrining yang dapat menilai secara akurat aspek perkembangan utama termasuk komponen bahasa dan visual-motor. Developmental quotient (DQ) adalah skor yang menggambarkan proporsi perkembangan yang normal anak pada usia tersebut. Secara aritmetika, DQ dihitung dengan membagi usia ekuivalen anak dengan usia kronologis anak, dan dinyatakan dalam persentase perkembangan yang diharapkan untuk usia kronologis. Language quotient (LQ) adalah total atau gabungan usia ekivalen bahasa (language age-equivalent) dibagi dengan usia kronologis dikalikan 100. Language quotient (LQ) merupakan sinonim dari CLAMS DQ. Keterlambatan bahasa didefinisikan menggunakan Skala CAPUTE, dengan $D Q C L A M S<85$.

Data yang diambil tersebut dimasukkan ke dalam program perangkat lunak SPSS ${ }^{\circledast} 22$. Data dianalisis menggunakan chi-square. Tingkat kemaknaan dalam penelitian ini dinyatakan bila $\mathrm{p}<0,05$.

\section{Hasil}

Pada penelitian ini didapatkan dari 51 anak yang memenuhi kriteria inklusi, didapatkan 33 anak perempuan $(64,7 \%)$ dan 18 anak laki-laki (35,3\%). Rerata umur 2 tahun 5 bulan $( \pm 0,6)$, terbagi 11 $(21,6 \%)$ berusia di bawah 2 tahun dan $40(78,4 \%)$ anak 2 tahun ke atas. 
Usia ibu kurang dari 30 tahun sebanyak 24 $(47,1 \%)$ dan $27(52,9 \%)$ ibu berusia lebih dari sama dengan 30 tahun dari anak yang diteliti. Tingkat pendidikan ibu lulus SMA 37 (72,5\%) dan sarjana 14 $(27,5 \%)$ orang. Sementara untuk ayah didapatkan 33 $(64,7 \%)$ lulus SMA dan 18 (35,3\%) sarjana. Dari 51 anak, ibu yang bekerja sebagai ibu rumah tangga 33 $(64,7 \%)$ dan seluruh ayah yang bekerja 51 (100\%).

Usia anak saat pertama kali menggunakan gawai didapatkan $20(39,2 \%)$ yang menggunakan gawai sejak usia kurang dari 2 tahun dan $31(60,8 \%)$ yang menggunakan gawai sejak usia lebih dari sama dengan 2 tahun. Didapatkan juga 15 (39,2\%) dengan frekuensi penggunaan gawai kurang dari sama dengan 2 hari dalam seminggu dan $36(70,6 \%)$ anak dengan frekuensi penggunaan gawai lebih dari 2 hari dalam seminggu. Rerata penggunaan gawai dalam sehari didapatkan $41(80,4 \%)$ anak dengan penggunaan kurang dari 2 jam dan $10(19,6 \%)$ dengan penggunaan gawai lebih dari sama dengan 2 jam. Dari 51 anak, $34(66,7 \%)$ anak yang menggunakan gawai berada dalam pengawasan orang tua. Sementara 17 (33,3\%) anak tidak dalam pengawasan orang tua. Karakteristik sampel dari penelitian ini tertera pada Tabel 1 .

Hubungan penggunaan gawai dengan keterlambatan bahasa diperoleh dengan menggunakan analisis chi-square. Dari 51 anak sampel penelitian didapatkan $3(5,9 \%)$ anak dengan hasil DQ Clams kurang dari sama dengan 85, dan 48 (94,1\%) dengan hasil DQ Clams lebih dari 85. DQ Clams yang

Tabel 1. Karakteristik penggunaan gawai pada anak

\begin{tabular}{lc}
\hline Karakteristik & Hasil $(\mathrm{n}, \%)$ \\
\hline Usia awal (tahun) & \\
$\quad<2$ & $20(39,2)$ \\
$\quad \geq 2$ & $31(60,8)$ \\
Frekuensi* (hari) $^{\leq 2}$ & \\
$\quad>2$ & $15(29,4)$ \\
Lama penggunaan** (jam) & $36(70,6)$ \\
$\quad<2$ & \\
$\quad \geq 2$ & $41(80,4)$ \\
Pengawasan & $10(19,6)$ \\
$\quad$ Ya & \\
$\quad$ Tidak & $34(66,7)$ \\
\hline * dalam seminggu & $17(33,3)$ \\
** dalam 1 hari & \\
\hline
\end{tabular}

kurang dari sama dengan 85 dikatakan mengalami keterlambatan bahasa (Tabel 2).

Dari 51 anak sampel penelitian didapatkan 3 anak dengan keterlambatan bahasa (DQ Clams <85).

Tidak didapatkan adanya hubungan antara usia awal penggunaan gawai dengan keterlambatan bahasa $(p=0,152)$. Tidak terdapat perbedaan bermakna antara hubungan frekuensi penggunaan gawai dalam 1 minggu dengan keterlambatan bahasa $(\mathrm{p}=0,144)$. Tidak juga didapatkan adanya hubungan antara pengawasan penggunaan gawai dengan keterlambatan bahasa $(\mathrm{p}=0,207)$.

Terdapat hubungan yang bermakna antara lama penggunaan gawai dalam 1 hari yang lebih dari $2 \mathrm{jam} /$ hari dengan keterlambatan bahasa $(p=0,034)$. Pada hasil penelitian didapatkan anak yang menggunakan gawai lebih dari $2 \mathrm{jam} /$ hari memiliki risiko terhadap keterlambatan bahasa sebesar 0.07 kali lebih besar $(\mathrm{RR}=0,07,95 \% \mathrm{CI}: 0,008-1,240)$ jika dibandingkan dengan anak yang menggunakan gawai kurang dari 2 jam/hari

\section{Pembahasan}

Pada penelitian ini telah ditunjukkan pola hubungan negatif antara penggunaan gawai sebelum usia 2 tahun dengan keterlambatan bahasa pada seorang anak.

Pada penelitian ini didapatkan 21,6\% anak berusia di bawah 2 tahun sudah mulai diberikan paparan terhadap gawai. Hal tersebut tidak sesuai dengan rekomendasi American Academy of Pediatrics, Rekomendasi penggunaan gawai sebaiknya pada anak berusia di atas 2 tahun karena hal ini dapat berkaitan dengan gangguan perkembangan, pemusatan perhatian, dan gangguan dalam perkembangan bahasa. ${ }^{10,11}$

Pada penelitian ini, dari 51 anak sampel penelitian didapatkan 3 anak dengan keterlambatan bahasa. Meskipun dengan pengawasan orang tua, tidak didapatkan adanya hubungan antara usia awal penggunaan gawai dengan keterlambatan Bahasa. .

Penggunaan gawai dengan frekuensi kurang dari 2 kali dalam 1 minggu dinyatakan dengan tidak adanya hubungan frekuensi penggunaan gawai dengan keterlambatan bahasa .

Pada hasil penelitian anak yang menggunakan gawai lebih dari 2 jam per hari memiliki risiko terhadap keterlambatan bahasa dibandingkan dengan 
Rae Fernandez dkk: Hubungan penggunaan gawai dengan keterlambatan bahasa

Tabel 2. Distribusi karakteristik hasil DQ Clams anak sampel peneliti

\begin{tabular}{|c|c|c|}
\hline \multirow{2}{*}{ Karakteristik } & \multicolumn{2}{|c|}{ DQ Clams (n,\%) } \\
\hline & Keterlambatan bahasa & Tidak terlambat bahasa \\
\hline \multicolumn{3}{|l|}{ Jenis kelamin } \\
\hline Laki-laki & $1(1)$ & $17(33)$ \\
\hline Perempuan & $2(3)$ & $31(60)$ \\
\hline \multicolumn{3}{|l|}{ Usia (tahun) } \\
\hline$<2$ & 0 & $11(21)$ \\
\hline$\geq 2$ & $3(6)$ & $37(72)$ \\
\hline \multicolumn{3}{|l|}{ Berat badan lahir (BBL) } \\
\hline$<2500$ & 0 & $24(47)$ \\
\hline$\geq 2500$ & $3(6)$ & $24(47)$ \\
\hline \multicolumn{3}{|l|}{ Usia Ibu (tahun) } \\
\hline$<30$ & $2(3)$ & $31(60)$ \\
\hline$\geq 30$ & $1(1)$ & $17(33)$ \\
\hline \multicolumn{3}{|l|}{ Pendidikan ibu } \\
\hline Lulusan SMA/sederajat & $1(1)$ & $17(33)$ \\
\hline Sarjana & $2(3)$ & $31(60)$ \\
\hline \multicolumn{3}{|l|}{ Pekerjaan ibu } \\
\hline Ibu rumah tangga & 0 & $11(21)$ \\
\hline Lain-lain & $3(6)$ & $37(72)$ \\
\hline \multicolumn{3}{|l|}{ Pendidikan ayah } \\
\hline Lulusan SMA/sederajat & $2(3)$ & $31(60)$ \\
\hline Sarjana & $1(1)$ & $17(33)$ \\
\hline \multicolumn{3}{|l|}{ Pekerjaan ayah } \\
\hline Bekerja & $3(5,8)$ & $48(94,1)$ \\
\hline Tidak bekerja & $0(0)$ & $0(0)$ \\
\hline \multicolumn{3}{|l|}{ Usia awal (tahun) } \\
\hline$<2$ & $0(0)$ & $20(39,1)$ \\
\hline$\geq 2$ & $3(6)$ & $28(54,9)$ \\
\hline \multicolumn{3}{|c|}{ Frekuensi dalam 1 minggu (hari) } \\
\hline$\leq 2$ & $2(3)$ & $13(25,4)$ \\
\hline$>2$ & $1(1)$ & $35(68,6)$ \\
\hline \multicolumn{3}{|c|}{ Lama Penggunaan dalam 1 hari (jam) } \\
\hline$<2$ & $1(1)$ & $40(78,4)$ \\
\hline$\geq 2$ & $2(3)$ & $8(15,6)$ \\
\hline \multicolumn{3}{|l|}{ Pengawasan } \\
\hline Ya & $3(6)$ & $31(60,7)$ \\
\hline Tidak & $0(0)$ & $17(33,3)$ \\
\hline
\end{tabular}

anak yang menggunakan gawai kurang dari 2 jam per hari. Hal ini berbeda dengan hasil penelitian Byeon $\mathrm{dkk}^{15}$ pada tahun 2015. Byeon melaporkan bahwa anak yang menonton televisi selama lebih dari 2 jam dan kurang dari 3 jam per hari memiliki 2,7 kali risiko keterlambatan bahasa dibandingkan dengan yang hanya kurang dari 1 jam. Sementara anak yang menonton televisi lebih dari 3 jam per hari memiliki risiko kurang lebih 3 kali lebih banyak mendapatkan keterlambatan bahasa. Risiko keterlambatan bahasa meningkat secara proporsional dengan semakin lama anak menonton televisi.

Chonchaiya $\mathrm{dkk}^{16}$ melaporkan bahwa anak yang mengalami keterlambatan bahasa menghabiskan waktu 3,05 kali lebih banyak menonton televisi daripada anak normal. Anak yang mulai menonton televisi pada 
usia kurang dari 12 bulan dan menonton televisi lebih dari 2 jam per hari kira-kira enam kali lebih mungkin mengalami keterlambatan bahasa. Zimmerman $\mathrm{dkk}^{17}$ mengatakan adanya hubungan yang signifikan antara penggunaan gawai dan keterlambatan bahasa ekspresif sebesar 1,49 kali. Hubungan ini lebih menonjol pada anak yang dilaporkan menggunakan gawai sebesar 2,11 kali. Risiko keterlambatan bahasa meningkat secara proporsional dengan semakin lama anak menonton TV.

Namun, mekanisme sebab akibat dari efek semacam itu, jika ada, tidak jelas. Anak di bawah 2 tahun yang menghabiskan lebih banyak waktu menggunakan gawai menghabiskan lebih sedikit waktu dalam kegiatan lain, seperti bermain bebas imajinatif, interaksi dengan orang dewasa, dan sebagainya, yang akan bermanfaat bagi perkembangan kognitif mereka. Beberapa orang tua juga beranggapan bahwa bahkan pada usia muda penggunaan gawai umumnya dapat mendidik, tetapi penelitian ini menunjukkan bahwa penggunaan gawai untuk anak yang sangat muda tidak membantu perkembangan kognitif dan mungkin memang berbahaya terhadap aspek perkembangan bahasa pada seorang anak. Penggunaan gawai pada usia dini menyebabkan anak menjadi pendengar pasif. Komunikasi hanya berjalan satu arah, dalam hal ini ialah respon. Anak akan bermain peran sebagai pendengar tanpa mencerna dan memproses informasi yang masuk.

\section{Kesimpulan}

Berdasarkan penelitian ini mengenai hubungan intensitas penggunaan gawai dan keterlambatan bahasa pada anak didapatkan adanya hubungan yang bermakna antara lama penggunan gawai yang lebih dari $2 \mathrm{jam} /$ hari dengan keterlambatan bahasa. Sedangkan tidak ada hubungan bermakna antara frekuensi penggunaan gawai dalam waktu 1 minggu dengan keterlambatan bahasa.

\section{Daftar pustaka}

1. American Academy of Pediatrics. Media education. Pediatrics 2010;126:1012-7.
2. American Academy of Pediatrics. Media use by children younger than 2 years. Pediatrics 2011;128:1040-5.

3. RideoutVJ, HamelE. The media family: electronic media in the lives of infants, toddlers, preschoolers, and their parents. Menlo Park, CA: Kaiser Family Foundation; 2006.

4. Glascoe FH. Early detection of developmental and behavioral problems. Pediatrics in Rev2000; 21:272-80.

5. The Royal Children's Hospital Melbourne. Developmental delay: an information guide for parents. Melbourne: The Royal Children's Hospital; 2009.

6. Herzog CE. Disorder of hearing, Speech and Language. Nelson Textbook of Paediatrics. Edisi Ke-21. Elsevier; 2020.

7. Narendra M, Sularyo S, Soetjiningsih, Suyitno H, Ranuh IGN, penyunting. Buku ajar I tumbuh kembang anak dan remaja. Jakarta: Sagung Seto; 2002.h.86-94.

8. Rusmil K, Hernawati I, Fadlyana E, Dhamayanti M, Dashriati, Herniyati S, dkk. Pedoman pelaksanaan stimulasi, deteksi dini dan intervensi dini tumbuh kembang anak di tingkat pelayanan kesehatan dasar. Jakarta: Depkes RI; 2005. h.71-86.

9. Linebarger DL, Walker D. Infants' and toddlers' television viewing and language outcomes. Am Behav Sci 2005;48,62445.

10. Zimmerman FJ, Christakis DA. Children's television viewing and cognitive outcomes: a longitudinal analysis of national data. Arch Pediatr Adolesc Med 2005;159:619-2.

11. Christakis DA, Zimmerman FJ, DiGiuseppe DL, McCarty CA. Early television exposure and subsequent attentional problems in children. Pediatrics 2004;113:708-13.

12. Kelly DP, Sally JI. Disorders of speech and language. Dalam: Levine MD, Carey WB, Crocker AC, penyunting. Edisi ke3. Developmental-behavioral pediatrics. Philadelphia: WB Saunders; 1999.

13. Al Harbi SS. The Influence of Media in Children's Language Development. J Educ Dev Psychol 2015;5:1.

14. Schmidt ME, Rich M, Rifas-Schiman SL, Oken E, Taveras EM. Television viewing in infancy and child cognition at 3 years of age in a US cohort. Pediatrics 2009;123:370-5.

15. Byeon $\mathrm{H}$, Hong S. Relationship between television viewing and language delay in toddlers: evidence from a Korea national cross-sectional survey. PLoS ONE 2015;10: e0120663.

16. Chonchaiya, Weerasak, and Chandhita Pruksananonda. "Television viewing associates with delayed language development." Acta Paediatrica Int J Paediatr 2008;97:977-82.

17. Zimmerman FJ, Christakis DA, Meltzoff AN. Associations between media viewing and language development in children under age 2 years. J Pediatr 2007;151:364-68. 